\title{
8 Challenges and Opportunities for Saline Agriculture in Coastal Bangladesh
}

\author{
Atiq Rahman and Md. Nasir Uddin
}

\section{CONTENTS}

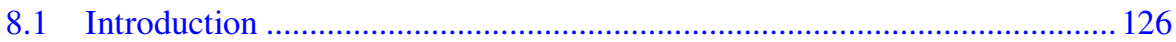

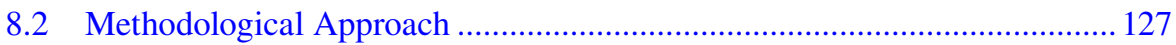

8.2.1 Key Feature of Case Study Area ............................................... 127

8.2.2 Identifying the Drivers of Coastal Salinity Intrusion...................... 127

8.2.2.1 Preliminary Analysis of Sea-Level Rise

(SLR) and Ocean Warming

8.2.2.2 Tropical Cyclonic Storm Surge

Analysis (1901-2020).................................................. 128

8.2.3 Spatial Analysis of Coastal Soil Salinity ....................................... 128

8.2.4 Identifying the Challenge and Opportunity of

Saline Agriculture................................................................... 128

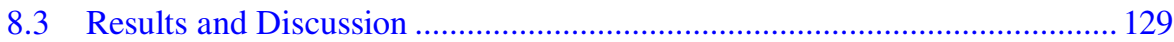

8.3.1 Drivers of Coastal Salinity in Bangladesh .................................... 129

8.3.1.1 Mapping of Sea-Level Rise and Sea Surface

Temperature (SST) ................................................... 129

8.3.1.2 Long-Term Tropical Cyclonic Storm Surge

Mapping (1901-2020) .................................................... 130

8.3.2 Spatial Analysis and Mapping of Soil Salinity............................... 134

8.3.3 Constraints of Coastal Agricultural Development .......................... 137

8.3.3.1 Salinity Impacts on Agriculture Systems ........................ 137

8.3.3.2 Salinity Impacts on Fisheries Resources ........................ 137

8.3.3.3 Salinity Impacts on Livestock Systems ......................... 138

8.3.3.4 Salinity Impacts on Human Mobility ............................. 138

8.3.4 Opportunities for Future Saline Agriculture ................................... 138

8.3.4.1 New Technology Development ...................................... 139

8.3.4.2 Community-Based Adaptation (CBA) in Coastal

Bangladesh ............................................................. 140

8.3.4.3 The Sundarbans Mangrove Forest and Agriculture........... 140

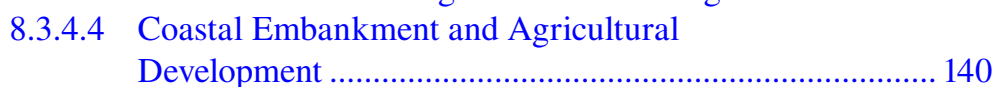

DOI: 10.1201/9781003112327-8 12 


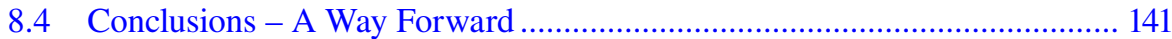

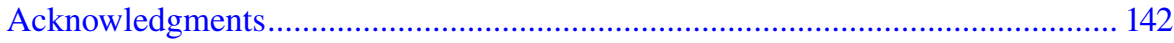

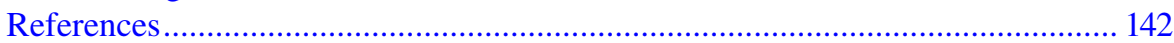

\subsection{INTRODUCTION}

Populations living in deltas (low-lying coastal floodplains of the world's major rivers) are increasingly vulnerable to risks from tropical cyclones, coastal floods, storm surges, sea-level rise (SLR), salinity, shoreline erosion and accretion, and pollution (IPCC 2014; Barbier 2015). Agriculture in delta landscapes is particularly vulnerable to climate change. The Intergovernmental Panel on Climate Change (IPCC) has indicated that in South Asia, agricultural crop yield could be reduced by up to $30 \%$ by 2050 because of a changed climate (IPCC 2014).

Bangladesh is located in the tropical zone and is highly prone to natural disasters like riverine and tidal floods, tropical cyclones, storm surges, heat stress, hailstorms, lightning strikes, drought, SLR, and salinity intrusion on land and in water (Rasid and Paul 2013). The coastal community of Bangladesh is highly dependent on agricultural production from crops, fish, and livestock. Local climatic factors are favorable for a wide range of crop cultivation and production in coastal areas (Uddin et al. 2019). However, recent studies have revealed that extreme climate events (e.g., coastal floods, cyclones, storm surges, and SLR) are increasing every year, devastating lives and livelihoods, and decreasing agricultural production in coastal and island Bangladesh (Uddin et al. 2019). This decrease in food production and availability represents a challenge and threat to the capacity of coastal communities to exercise their right to food.

SLR-induced salinity in soil and water threatens both crop yields and economic development in coastal Bangladesh. River water and groundwater are both influenced by rainfall, river flow, upstream withdrawal of water, salinity, cyclonic storm surges, and tidal flood. Over the last few decades, the salinity of rivers in southern districts has increased by about $45 \%$ and over 20 million people are affected by salinity in the water along the coastal region of Bangladesh (Dasgupta et al. 2018). The increased frequency of cyclonic events and intensity of associated storm surges intensifies the risk of salinity intrusion in coastal areas. There is a strong association between the presence of salinity and the storm surges that cause flooding along the Bangladesh coast (Paul and Rashid 2017).

A number of adaptation measures have been undertaken to increase agricultural production in affected communities. These include the cultivation of vegetables on floating beds, the planting of faster maturing crop species and varieties with institutional support, the promotion of alternative livelihoods, and the planting of saline tolerant trees on embankments (Aryal et al. 2020). A few recent studies have shown that community-based adaptation (CBA) systems reduce the risk and increase the benefits to smallholder farmers (Schipper et al. 2014).

Few papers have described the SLR-induced salinity and its impacts on coastal agriculture practices. Based on primary and secondary data, this chapter, therefore, explores salinity risk areas using long-term climate risk analysis and coping measures that communities in the coastal areas of Bangladesh use to minimize their 
vulnerability to coastal floods, cyclone hazards, and salinity intrusion. We integrate and analyze expert judgments along with community perceptions on SLR-induced salinity and its direct effects on local agricultural systems. We show how climateinduced salinity impacts agriculture, and identify opportunities for future coastal saline agricultural management.

\subsection{METHODOLOGICAL APPROACH}

\subsubsection{Key Feature of Case Study Area}

Bangladesh has 19 coastal districts (and 147 subdistricts), which extend over 47,150 sq $\mathrm{km}$ (around $32 \%$ of the total land area). About 35 million people (6.9 million households), or $28 \%$ of the country's total population live in these areas (BBS 2011). The coastal zone can be classified based on three characteristics: the level of tidal fluctuation, the salinity of surface and groundwater, and the risks from cyclones, storm surges, and tidal influences (Brammer 2014). The 19 coastal districts have been further divided into interior (7 districts, 48 subdistricts) and exposed (12 districts, 99 subdistricts) zones, with regard to distance from the coast or estuaries, under the Integrated Coastal Zone Management Project (ICZMP) of the Water Resources Planning Organization (WARPO). The coastal zone of Bangladesh is divided into three regions, the western zone (Ganges tidal plain), the central zone (Meghna deltaic plain), and eastern zone (Chittagong coastal plain). The coastal zone is characterized by a vast network of rivers and channels, an enormous discharge of water with huge amount of suspended sediment, many islands, a strong tidal influence, and tropical cyclones and storm surges (CCC 2016). About $70 \%$ of total farmers in coastal areas are sharecroppers while more than $53 \%$ of the total coastal population are functionally landless, live below the poverty line, and have no cultivable land (CCC 2016).

\subsubsection{Identifying the Drivers of Coastal Salinity Intrusion}

This study reviewed the secondary literature and interviewed 10 key experts to quantify the drivers of salinity intrusion in the coastal belt of Bangladesh. Using a semi-structured questionnaire, experts were asked about: (a) causes of salinity, (b) salinity intrusion in coastal agriculture land, (c) the historical trend of coastal salinity intrusion, (d) the major impacts of soil salinity on coastal agriculture, and (e) saline agriculture management for sustainable development. In addition, we conducted a detailed spatial analysis of SLR, sea-level temperatures, and cyclones in coastal areas.

\subsubsection{Preliminary Analysis of Sea-Level Rise (SLR) and Ocean Warming}

Techniques were used to analyze and map SLR and track ocean warming in the Bengal basin. Daily tidal gauge SLR records for the period of 1980-2010 were collected from the hydrography department of Bangladesh Inland Water Transport Authority (BIWTA). To derive the annual SLR trends of ground observation stations, we used a simple linear regression model $(\mathrm{Y}=\beta \mathrm{X}+\alpha)$ in the $\mathrm{R}$ platform. To explore the sea surface temperature (SST) in the Bay of Bengal, we used the monthly 
HadISST V1.1 $\left(1^{\circ} \times 1^{\circ}\right)$ NetCDF dataset of 39 years (1980-2019), retrieved from the NCAR global climate guide data hub (NCAR 2020). Using these data, we developed a simple linear regression to identify the trend in ocean warming (SST) for the Basin area. Additionally, based on the ASTER NASA LPDAAC (30m) GDEMV3, we identified the SLR (0cmSLR, 40cmSLR, 80cmSLR, 1mSLR) affected crops land of coastal subdistricts using ArcGIS 10.5 platform.

\subsubsection{Tropical Cyclonic Storm Surge Analysis (1901-2020)}

Data on historical tropical cyclone tracks (1901-2020) were collected from the NOAA National Centers for Environmental Information IBTrACS data sets. We extracted the wind speed and pressure of individual tracks along with their coordinates. The dataset contained comprehensive information on each tropical cyclone and storm, a synoptic history, meteorological statistics, casualties, and damages. To estimate the damage area of individual cyclones, we created a buffer area based on wind speed and pressure around the tracks in ArcGIS 10.7.1 platform. Then the storm risk map was prepared using frequency and kennel density functions. Damage to agriculture due to storms was collected from national disaster census (BBS 2015) and national published daily newspapers. Considering the secondary damage data and generated risk data, the subdistricts were ranked based on the loss and damage scenarios and the prepared cyclone and storm spatial risk map for the coastal regions.

\subsubsection{Spatial Analysis of Coastal Soll Salinity}

Subdistrict-level soil salinity data were collected from the subdistrict supplements published by Soil Resource Development Institute (SRDI) of Bangladesh. On average 41 samples were collected from each subdistrict (SRDI 2020). The data were classified into four categories: very slightly saline $(<2 \mathrm{ppt})$, slightly saline (3-6 pt), strongly saline (7-12 ppt), very strongly saline (> 12ppt), and the soil salinity stress areas were mapped using the ArcGIS platform.

\subsubsection{Identifying the Challenge and Opportunity of Saline Agriculture}

Community-based information and the grey literature were reviewed to collect key relevant information including the challenges and opportunities for coastal saline agriculture, coastal SLR and cyclonic storm surge induced salinity, and impacts on crop production. Local-level information was collected from 34 Focus Group Discussions (FGDs) held at the most vulnerable subdistricts of 15 most vulnerable coastal districts. The clusters were selected through Geographic Information System- GIS mapping based on a gradient of salinity. All these FGDs were conducted based on the checklist developed to gain in-depth information on coastal climate change-induced extremes, impacts on agriculture, and types of community led and exogenous adaptation measures practiced. A total of 15 stakeholder consultation workshops were conducted in the study districts. The synthesis research findings from subdistrict-level group discussions were presented in district-level consultation workshops. The findings from the local-level discussions and interviews were validated through these workshops. Based on the secondary and field observations, 
we prepared an opportunities matrix for future saline agriculture management in coastal Bangladesh.

\subsection{RESULTS AND DISCUSSION}

The study identified four climate change-induced factors that have direct impacts on coastal agricultural land and production in the study areas: SLR, cyclonic storm surges, tidal surge/waves, and coastal flooding. Salinity is one of the main constraints for regular crop production in the southern region. This study also discussed the opportunities for future coastal saline agriculture management.

\subsubsection{Drivers of Coastal Salinity in Bangladesh}

From expert observations and the literature, we found that the main causes of increased soil salinity along the coast are: the withdrawal of fresh river water from upstream, irregular rainfall, the introduction of brackish water for the culture of shrimp, the faulty management of sluice gates and polders, the regular intrusion of tidal saline water during high tide in the unprotected lands, and the capillary rise of soluble salts from shallow groundwater towards the soil surface. About 1 Mha in the southern area is affected by soil salinity. Some of the new lands in Satkhira, Patuakhali, Barguna, Barisal, Jhalokati, and Pirojpur districts have been affected significantly by different degrees of soil salinity during the last few decades. Several recent studies (Dasgupta et al. 2014; Salehin et al. 2018) have identified multiple reasons for salinity intrusion in the coastal area of Bangladesh. Broadly, these include changes to natural, socio-economic and political systems (Mahmuduzzaman et al. 2014). The literature review helped to quantify a few key points which play a role in increasing salinity intrusion; these are firstly the biophysical context of coastal Bangladesh, secondly climate change-induced extremes (e.g., SLR, increased numbers of tropical cyclones, storm surges, and coastal floods - Dasgupta et al. 2015; Haque 2006), thirdly changes to the socio-economic system such as increased shrimp cultivation in agricultural land (Clarke et al. 2015), and fourthly the establishment of the Farakka Barrage in the upstream Ganges River which caused increased seawater intrusion into the basin area of coastal Bangladesh (Rahman and Rahaman 2018).

\subsubsection{Mapping of Sea-Level Rise and Sea Surface Temperature (SST)}

Analysis of data from tidal gauges revealed a significant rising trend in sea level in south coastal regions of Bangladesh during the period 1980-2010 $(P<0.000)$, with a rate of rise of $10.4 \mathrm{~mm}$ per year. Monthly analysis showed that the lowest trend (3.1 mm/year) was in May, and the highest trend (10.9 mm/year) was in November. These results are consistent with other previous studies (Brammer 2014), but they are higher than the reported average for north India $(1.3 \mathrm{~mm} /$ year - Unnikrishnan and Shankar 2007) and the global average of $3.6 \mathrm{~mm} /$ year (Rignot et al. 2009). Different coastal regions of Bangladesh have differing rising trends (Table 8.1). The highest increasing trend (21.0 $\mathrm{mm}$ per year) was in the western region (Khepupara), whereas the rates of SLR on the central and eastern coast were 7.2 and $8.4 \mathrm{~mm} /$ year respectively. 


\section{TABLE 8.1}

\section{Summary of Sea-level Rise (SLR) Trend Analysis in Four Coastal Stations of Bangladesh}

\begin{tabular}{lcclcc} 
Tide Gauge Stations & Latitude $\left(^{(}\right)$ & Longitude $\left(^{(}\right)$ & Regions & Trends $(\mathbf{m m} / \mathbf{y r s}$.) & $\boldsymbol{P}$-value \\
Hiron Point & 21.80 & 89.47 & Western & $\mathrm{Y}=4.91 \mathrm{x}-516.40$ & 0.001 \\
Khepupara & 21.99 & 90.22 & Western & $\mathrm{Y}=21.0 \mathrm{x}-2903.34$ & 0.000 \\
Char Changa, Hatiya & 22.23 & 91.01 & Central & $\mathrm{Y}=7.22 \mathrm{x}-190.382$ & 0.049 \\
Conx's Bazar & 21.43 & 92.00 & Eastern & $\mathrm{Y}=8.39 \mathrm{x}-4027.29$ & 0.000 \\
\hline
\end{tabular}

Our study showed that the south coastal ocean is rapidly warning. Near the south western coast (around Hiron Point), the SST has a highly significant $(P<0.001)$ increasing decadal trend of over $1.3^{\circ} \mathrm{C}$ in the monsoon (April, May) and about $0.7^{\circ} \mathrm{C}$ in the post-monsoon period (October, November). Near the south eastern coast, SST has significant rising trends $\left(0.8^{\circ} \mathrm{C}\right.$ per 10 years in the monsoon and about $0.5^{\circ} \mathrm{C}$ per 10 years in the post-monsoon period).

The increasing trends of SLR have devastating effects on coastal ecosystems including increased erosion, the flooding of wetlands, and the contamination of agricultural soils with salt. Figure $8.1 \mathrm{~B}$ shows the districts of Bangladesh and the extent of inundation that would occur with a 40,80, or $100 \mathrm{~cm}$ rise in sea level. It can be seen that a $1 \mathrm{~m}$ rise in sea level would inundate the exposed coast and coastal islands and remove about $30 \%$ of the monsoon cropland of Bangladesh accounting for cropland in 103 tidal subdistricts in 15 districts (i.e., Satkhira, Khulna, Bagerhat, Barisal, Barguna, Patuakhali, Bhola, Noakhali, Shariatpur, Chandpur, Lakshmipur, and Feni). An $80 \mathrm{~cm}$ rise in sea level would inundate over $21 \%$ of the summer rice cropland in 88 subdistricts of the interior coast of Bangladesh (Figure 8.1B).

\subsubsection{Long-Term Tropical Cyclonic Storm Surge Mapping (1901-2020)}

An analysis of 245 cyclones over 119 years was undertaken in this study. We analyzed the density, synoptic behavior, wide speed, and pressure of 245 individual tropical cyclones from 1901 to 2020 to identify the risk-prone areas at the subdistrict scale (Figure 8.2A). We found 180 tracks for category 1 storms $(119-153 \mathrm{~km} / \mathrm{h}), 13$ tracks in category $2(154-177 \mathrm{~km} / \mathrm{h}), 11$ tracks for category $3(178-208 \mathrm{~km} / \mathrm{h}), 15$ tracks for category $4(209-251 \mathrm{~km} / \mathrm{h})$ and six tracks for category 5 storms $(252 \mathrm{~km} / \mathrm{h}$ or higher) (Figure 8.2A). In addition, we classified 483 tropical storms (pressure, wind speed and surge height) in which $\sim 63 \%$ storm surges occurred during SeptemberNovember and $\sim 38 \%$ occurred in April-July (1901-2020). The subdistrict scale damage mapping showed that the south central and south eastern part of the coast had the highest tropical cyclone risk. Figure 8.2B shows that the 41 subdistricts of high cyclone risk are in the districts of Barguna, Bhola, Jhalokati, Patuakhali, Feni, Noyakhali, and Chittagong. Our analysis shows that $\sim 79 \%$ of cyclone tracks hit the south western coast (Barguna and Khulna regions) in the month of April- July. The subdistricts of Chittagong and Patuakhali districts experienced the highest (96) and 


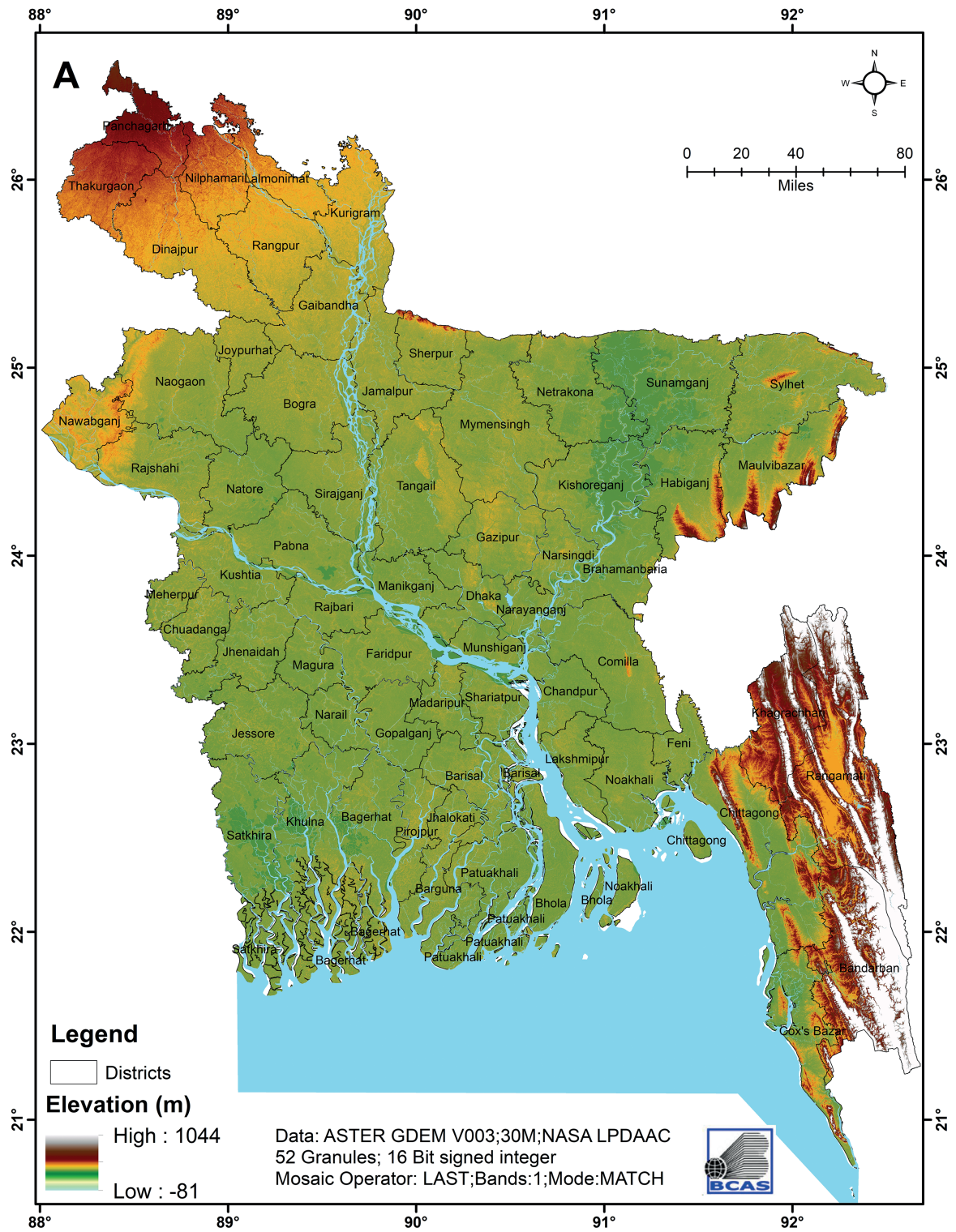

FIGURE 8.1 Mapping of ASTER NASA LPDAAC (30m) elevation along with districts boundary (A), sea-level rise affected subdistricts (using ocmSLR, 40cmSLR, 80cmSLR, and $1 \mathrm{mSLR}$ line graph) along with tidal water level (WL) observatories and tidal limit (B).

(Continued) 


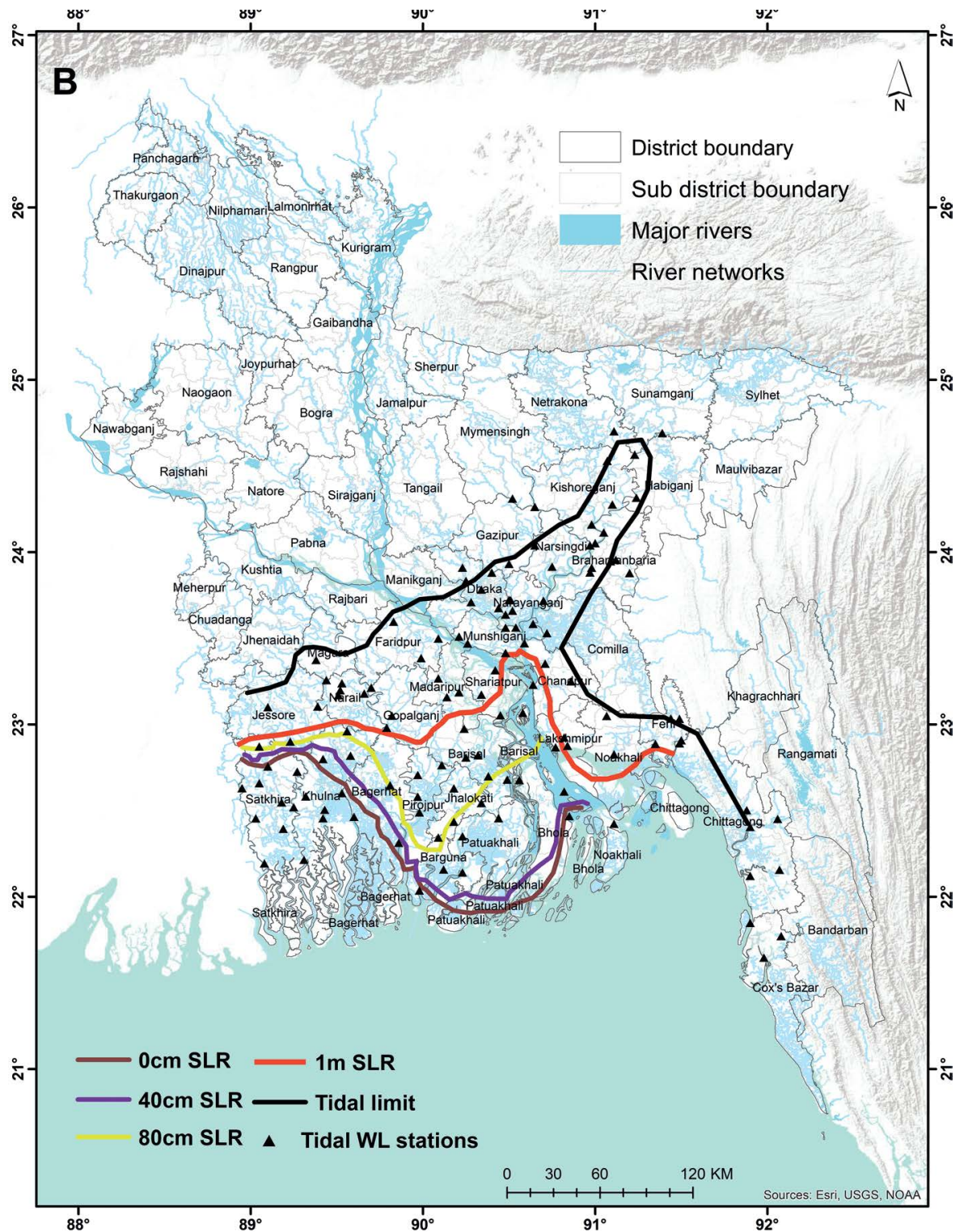

FIGURE 8.1 (Continued)

lowest (27) number of cyclones respectively (Figure 8.2B). From the analysis of longterm cyclone tracks, we found that over $89 \%$ cropland was affected and damaged about every three-year due to cyclonic storm surges in coastal areas. The last few major cyclones along with surge height (from Indian Meteorological Department, IMD), the affected districts, subdistricts, affected croplands, and the total loss and damage are summarized in Table 8.2. 


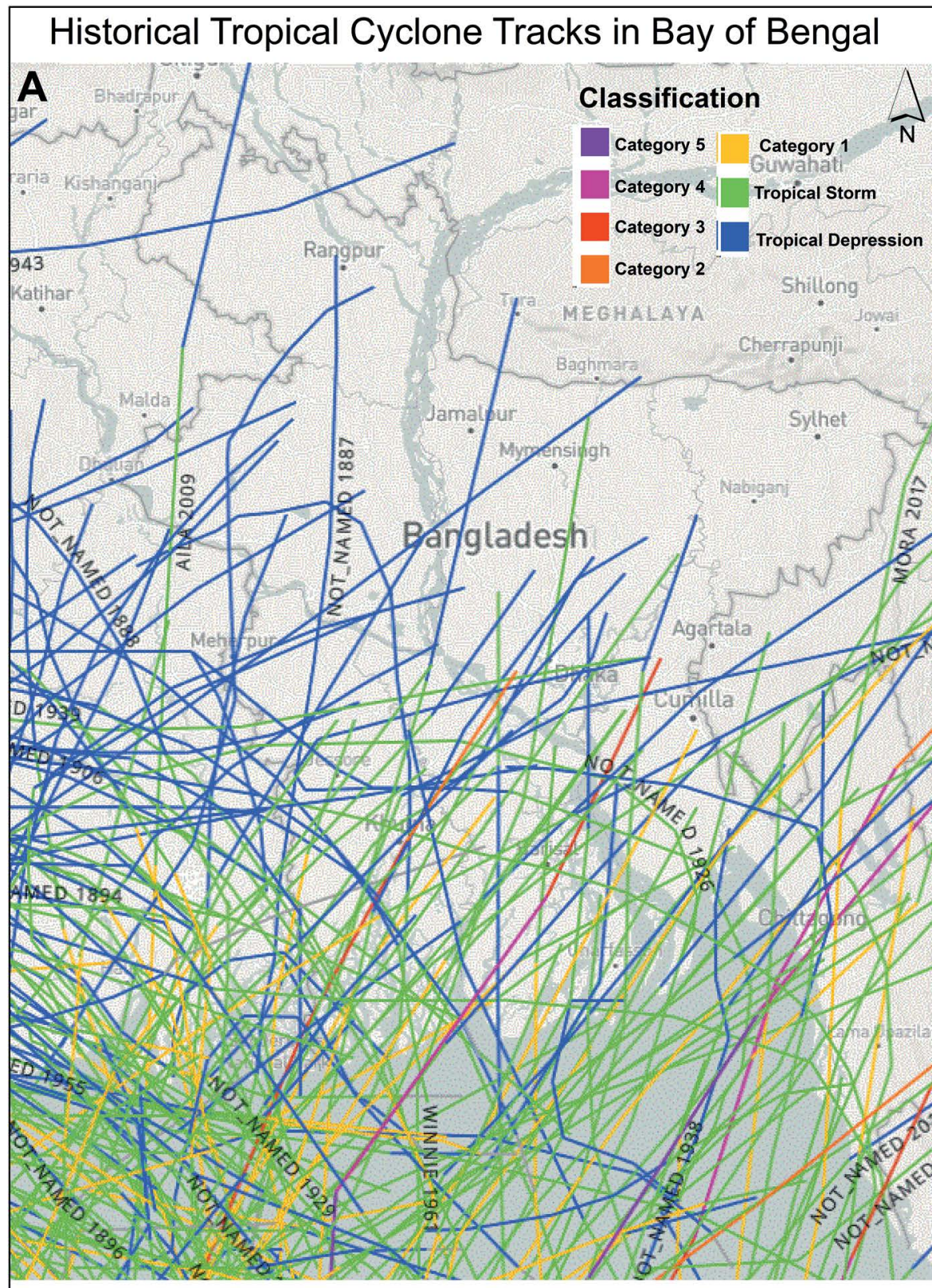

*Categories shown are based on the Saffir-Simpson Hurricane Wind Scale (NOAA,2020)

FIGURE 8.2 Historical tropical cyclone tracks (1901-2020) along with Saffir-Simpon classification (A), cyclone risk index map indicating the degree of risk at subdistrict level (B). 


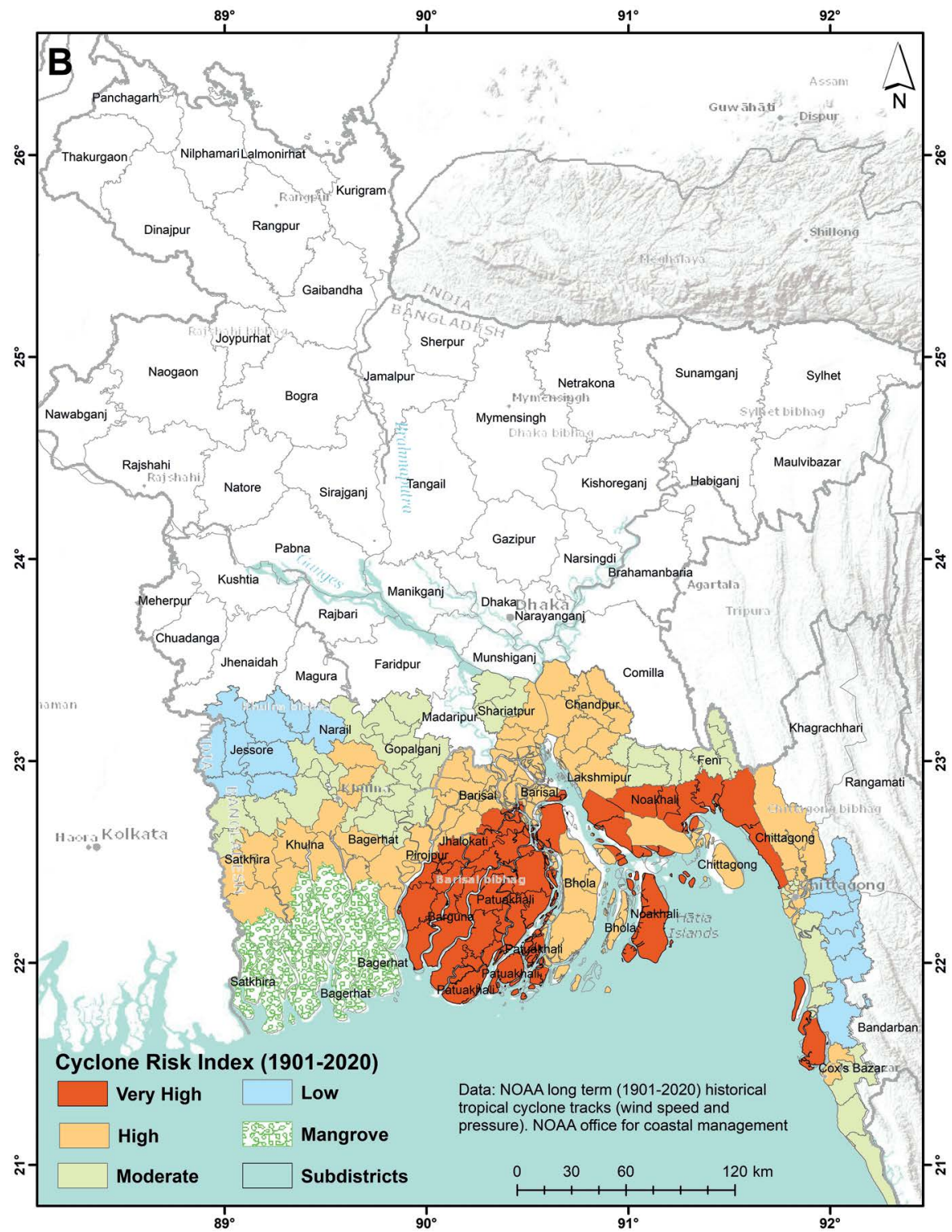

FIGURE 8.2 (Continued)

\subsubsection{Spatial Analysis and Mapping of Soll Salinity}

The salinity in the soil largely determined the crop productivity and potential land use in the coastal areas. Spatial analyses of variation in soil salinity in the topsoil and the subsoil shows that all coastal subdistricts are affected by salinity. Based on measures of soil $\mathrm{EC}_{\mathrm{e}}$, these coastal subdistricts are classified into four major 


\section{TABLE 8.2}

\section{Eight Major Severe Cyclones along with Storm Surge Height, Affected Districts, Farmland, and Total Loss and Damage}

\begin{tabular}{|c|c|c|c|c|}
\hline Cyclone Name & $\begin{array}{l}\text { Surge Height } \\
\text { (m) (IMD)* }\end{array}$ & Affected Areas & $\begin{array}{l}\text { Affected Farmland } \\
\text { (ha) (DAE)** }\end{array}$ & $\begin{array}{l}\text { Loss and Damage } \\
\text { (US \$M) }\end{array}$ \\
\hline $\begin{array}{l}\text { Amphan } \\
\text { (May 2020) }\end{array}$ & $3-5$ & $\begin{array}{l}\text { Over } 100 \text { villages of } \\
\text { nine districts in the } \\
\text { coastal divisions of } \\
\text { Khulna and Barisal }\end{array}$ & 176,000 & 130 \\
\hline Fani (April 2019) & 1.5 & 35 districts & 63,000 & 63.6 \\
\hline $\begin{array}{l}\text { Bulbul } \\
\text { (November 2019) }\end{array}$ & $1.2-1.5$ & $\begin{array}{l}\text { Khulna, Bagerhat } \\
\text { districts }\end{array}$ & 289,006 & 33 \\
\hline Mora (May 2017) & $1.2-1.5 \mathrm{~m}$ & $\begin{array}{l}\text { Chittagong, Cox’s } \\
\text { Bazar, and } \\
\text { Rangamati }\end{array}$ & NA & $\begin{array}{l}9 \text { deaths, } \\
52,000 \text { houses } \\
\text { Damaged }\end{array}$ \\
\hline Roanu (May 2016) & 2 & $\begin{array}{l}\text { Sandwip, Hatia, } \\
\text { Kutubdia, Sitakundu } \\
\text { and Feni, Chittagong, } \\
\text { and Cox's Bazar }\end{array}$ & NA & 31.8 \\
\hline $\begin{array}{l}\text { Mahasen } \\
\text { (May 2013) }\end{array}$ & 2 & $\begin{array}{l}\text { Chittagong, } \\
\text { Patuakhali, Noakhali } \\
\text { district }\end{array}$ & NA & $\begin{array}{l}49,000 \text { houses } \\
\text { destroyed and } \\
45,000 \text { houses } \\
\text { partially destroyed }\end{array}$ \\
\hline Aila (May 2009) & 3 & $\begin{array}{l}15 \text { districts of south } \\
\text { western part }\end{array}$ & 60,000 & $\sim 1,000$ \\
\hline $\begin{array}{l}\text { Sidr } \\
\text { (November 2007) }\end{array}$ & $3-5$ & $\begin{array}{l}\text { Sharankhola, } \\
\text { Patuakhali, Barguna, } \\
\text { and Jhalokati }\end{array}$ & $\sim 1,000,000$ & 2,310 \\
\hline \multicolumn{5}{|c|}{$\begin{array}{l}\text { * Storm surge height data taken from India Meteorological Department (IMD) dataset, } \\
\text { affected croplands and damage estimated by Department of Agricultural Extension (DAE) of } \\
\text { Bangladesh }\end{array}$} \\
\hline Source: Daily new & papers. & & & \\
\hline
\end{tabular}

divisions (a) very strongly saline (>15 dS/m), (b) strongly saline (8-15 dS/m), (c) slightly saline $(3-7 \mathrm{dS} / \mathrm{m})$, and (d) very slightly saline $(<2 \mathrm{dS} / \mathrm{m})$. The result shows most of the exposed coastal subdistricts of Satkhira, Barguna, and Chittagong districts and south western coastal areas are very strongly saline (Figure 8.3). Group discussions revealed that salinity increased in the dry season because less water flows from major rivers like the Ganges and Meghna, and there are frequent storm surges along with man-made salinity through intrusion of saline water for shrimp culture in Khulna and other coastal regions. In addition, salinity has increased from eastern coastal belts to the western coastal belt mainly due to the very low flow of upstream water from the Ganges and its tributaries during November-May because of water withdrawal at the Farraka Barrage on the Ganges in West Bengal of India 


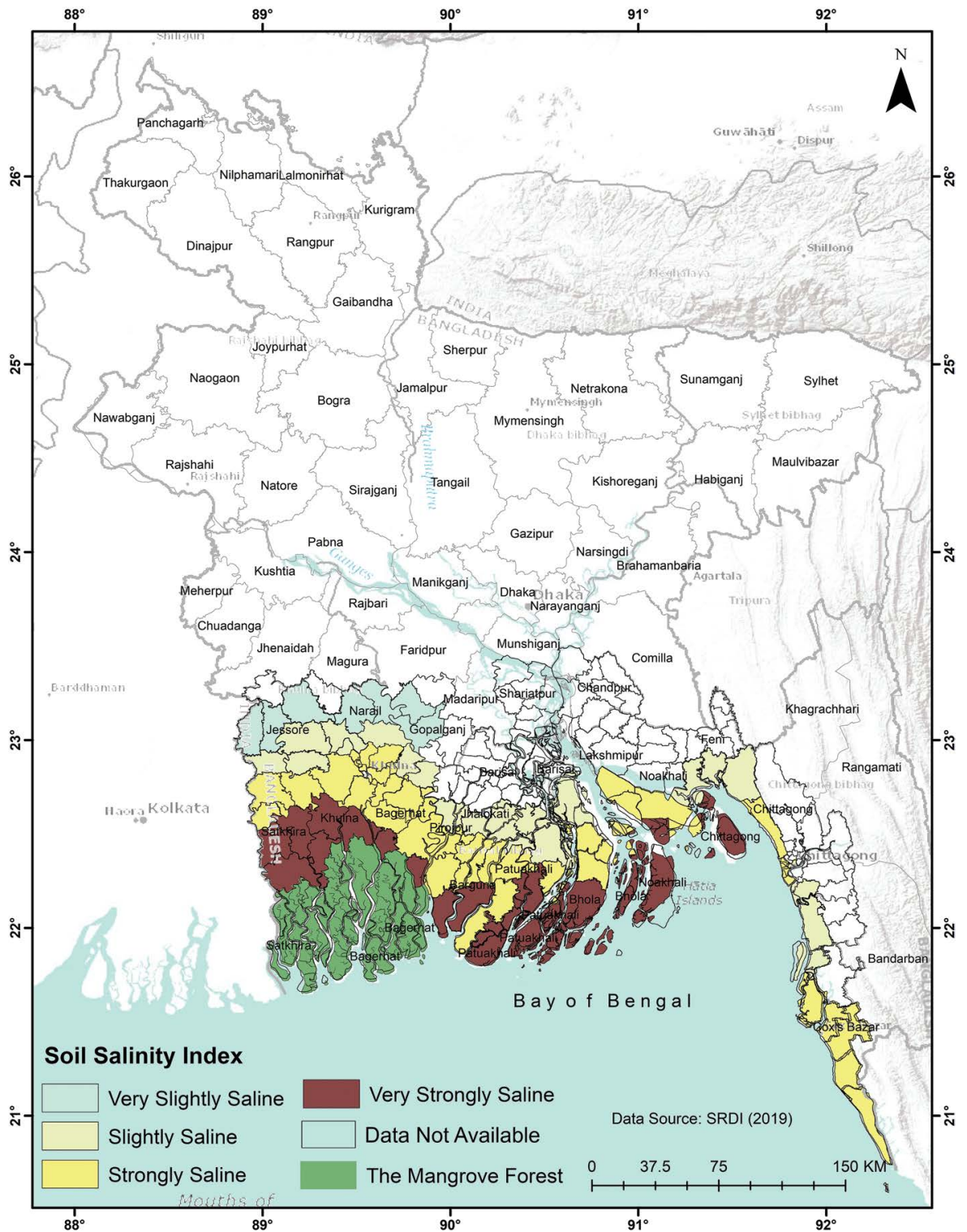

FIGURE 8.3 Soil salinity map of coastal Bangladesh.

(commissioned in 1974). The coastal area of Bangladesh has relatively less cropping intensity due to the rise of salinity during dry season and other constraints such as low soil fertility, river erosion, floods, late draining condition, heavy clay soils, the scarcity of irrigation water, exposure to cyclone storm surges, difficulties in communication, and remoteness from urban markets. 


\subsubsection{Constraints of Coastal Agricultural Development}

Our study suggests that the agricultural systems and cropping intensities in over 79 subdistricts of Khulna, Jessore, Satkhira, Bagerhat, Barguna, Narail, Gopalganj, Patuakhali, Barisal, Jhalokati, and Pirojpur districts and of coastal islands are seriously affected by saline stress, and as a consequence agricultural activities have been changing in coastal regions. Over the last 20 years, most of the rice land in coastal regions has been replaced by rice-shrimp farming (rice in the rainy season and shrimp in the dry season), indicating a sharp increase in shrimp cultivation over the coastal areas. Crop production in the study areas has declined following shrimp cultivation. In addition, the yield of wheat, jute, and sugarcane have been affected seriously, and it is now not possible to grow these crops because of soil salinization. Other constraints affecting coastal agricultural development include the limited availability of good-quality groundwater, a severe scarcity of quality irrigation water during the dry season, prolonged artificial waterlogging with saline water for agriculture, the presence of toxic potential acid sulfate soils in some areas, and the relatively high flooding depth during monsoon season for high yield variety rice crops.

\subsubsection{Salinity Impacts on Agriculture Systems}

SST has a strong influence on coastal climate and salinity (Ji et al. 2019). The gradual increasing scenarios of salinity intrusion into the coastal areas (soil, river, and groundwater) of Bangladesh is very threatening to the primary production system, coastal biodiversity, and human health (Amores et al. 2013; Islam et al. 2020; Uddin et al. 2019). According to the Soil Resources Development Institute (SRDI), the total amount of salt-affected land in Bangladesh was 83.3 Mha in 1973, which increased to $\sim 102$ Mha in 2000 , to $\sim 105.6$ Mha in 2009 , and is still continuing to increase (Chen and Mueller 2018). Salinity intrusion directly affects the livelihoods of farmers including rice cultivators and fisherfolk. Vegetation, soil quality, and infrastructure in these areas are also affected by salinity. The net cropped area in coastal Bangladesh has been decreasing over the last few years due to several factors and studies have identified salinity as the main cause for yield reduction in coastal agriculture (Baten et al. 2015). The extent and intensity of salinity are projected to increase due to climate change-induced saltwater intrusion. Other statistics that point to the trauma of salinity include: (a) salinity has decreased the production of wheat by $4.42 \mathrm{Mt}$ per year in coastal Bangladesh (Habiba et al. 2014), (b) 19 of 40 local rice varieties are already extinct and about four to five varieties have become rare in coastal areas, and (c) between 1975 and 2006 the number of cultivated winter vegetables has declined in coastal areas (Rahman et al. 2004).

\subsubsection{Salinity Impacts on Fisheries Resources}

Increased coastal salinity has affected fish yields, leading to substantial reductions in the inland open water fishery. Shrimp farming occurs on about 138,600 ha of coastal land in Satkhira (42,550 ha), Khulna (36,500 ha), and Bagerhat (49,550 ha) districts. Apart from these, the production of native freshwater fish species (e.g., rui, katla, carp, boal, tengra, golsha tengra, koi, shing, taki, khalisha, potka, kani magur, 
salbaim - all local names) is gradually declining due to increased salinity (Alam et al. 2017; Habiba et al. 2014).

\subsubsection{Salinity Impacts on Livestock Systems}

The 2014 IPCC assessment report showed that the projected impacts of climate change and extremes will affect livestock and livestock production systems. Increased salinity has significant negative impacts on livestock products in low-lying coastal floodplain. Our study has shown that in the last few decades, the area of grazing land and the intensity of grazing has decreased due to increased salinity and the loss of agricultural land in coastal areas. Qualitative assessments suggest that the aggregated impacts of coastal climatic factors including SLR-induced salinity, coastal floods, cyclonic storm surges, and waterlogging will substantially decrease domestic cattle production in coastal areas. Increased temperatures will also have adverse effects. In general, livestock perform best at temperatures between 10 and $30^{\circ} \mathrm{C}$; at temperatures above $30^{\circ} \mathrm{C}$, cattle, sheep, goats, pig, and chickens reduce their feed intake by $3-5 \%$ for each $1^{\circ} \mathrm{C}$ increase (Thornton et al. 2015). Our group discussions show that salinity will seriously affect the productivity and species composition and dynamics (quality and abundance of feed sources), resulting in overall livestock and poultry productivity decreases with increasing salinity. Increases in salinity in the study area will be negatively correlated with the changes in animal diets and the reduced nutrient availability for domestic cattle.

\subsubsection{Salinity Impacts on Human Mobility}

A number of studies have found that soil salinity has significant impacts on seasonal and internal migration in coastal Bangladesh (e.g., Chen and Mueller 2018). Coastal indigenous communities with traditional ways of life face unprecedented impacts from climate change-induced disasters. Households experienced both short- and long-term displacement as response to extreme climatic change events. Communities have their own indicators for predicting and adapting to these changes. Individuals, households, and community in coastal areas are already implementing traditional ways of adaptation to secure their livelihoods and development by trying to obtain better agricultural crops, and safe drinking water. Climate-induced migration, has negative impacts on community-based approaches used in coping with these changes. Human mobility from coast to urban cities has reduced the primary productivity and negatively affected agricultural development in coastal regions. As a result, climate-induced migration, is being recognized as a major potential threat to indigenous knowledge systems and strategies. Often men leave first, putting an extra domestic burden on the women left behind. This can lead to the loss of local innovation and locally led sectoral adaptation practices.

\subsubsection{Opportunities for fUtURe SALINE AGriculture}

In view of these climate change-induced extremes, farmers bear significant losses every year. Our study shows that a range of adaptations are required to ensure their survival and safeguard their livelihoods. Most of the adaptation plans were identified from government extension agents, non-government (NGO) project-based activities, 
and the findings of action research by research organizations and NGOs. The present study has developed a database on salinity tolerance of agricultural practices for community development, policy suggestions, and coastal crop and climate risk management. Based on an analysis of field observation and secondary literature, we broadly classified the coastal adaptation into following subsections.

\subsubsection{New Technology Development}

Different research institutes including the Bangladesh Rice Research Institute (BRRI), Bangladesh Institute of Nuclear Agriculture (BINA), and the Bangladesh Agriculture University (BAU) have developed and promoted salt-tolerant rice varieties (see Table 8.3 for details) and tidal and monsoon flood-tolerant varieties (BRRI rice 51 and 52; BINA rice 11 and 12). A number of studies conducted by BARC, BRRI, and DAE have focused on crop suitability in the coastal zone for the dry (rabi season). These have extended multi-crop farming systems with salt-tolerant vegetables, pulses, and oilseeds. The available salt-tolerant rabi field crops are sweet potato, green gram, linseed, groundnut, millet, sunflower, soybean, triticale, wheat, cowpea, mungbean, mustard. Vegetable and fruits include batisak, chilli, spinach, kangkong, garlic, china sak, Indian spinach, okra, water melon, red amaranth, and sunflower in the salt-affected coastal zone (Paul et al. 2020). Research has focused

\section{TABLE 8.3}

\section{Summary of Improved Salt-Tolerant Crop Varieties along with Intervention} Areas

\begin{tabular}{lll}
\multicolumn{1}{l}{ Improved Agricultural Crop } & \\
Crops & Varieties & Interventions Districts (Sub-Districts) \\
Rice & BRRI dhan 47, 53, 54, 55, and 61; & Khulna (Dumuria, Bhatiaghata, Dacope); \\
Vegetable & BINA dhan 8 and 10 & Satkhira (Shaymanagar, Debhatta, \\
& High yield variety water gourd, & Assasuni); Bagerhat (Fakirhat, Kachua, \\
& bitter gourd, cowpea, cucumber, & Chitalmari); Jhalokhati (Kathalia, \\
& red amaranth, jhinga, Indian & Rajabari, Amtali); Barguna (Pathargata,), \\
spinach & Patuakhali (Galachipa, Kolapara); \\
Sweet Potato & Cardinal, Diamont, BARI Sweet & Pirojpur (Nazipur, Bhandaria); Barisal \\
& Potato-8,9 and local varieties & (Wazipur, Agaailjhara); Bhola (Char \\
Pulse & BARI mung-1, 2,3,4,5,6 and & fession, Tajumuddin, Daulatkhan); \\
& BARI Khesari-6, BINA Mung-3, & Laksmhipur (Sadar, Ramgati); Noakhali \\
& Local Khesari & (Companyganj, Subornochar); Feni \\
Wheat & Shorab, Gourab, Prodip & (Sonagazi, Chokoria); Cox's Bazar \\
OilSeed (mustard) & BARI Sharisa-15 & (Moheskhali, Bashkhali); Chittagong \\
Barlie & Bari Barli-6 & (Sandwip) \\
Kawon & Bari Kawon-2, Bari Kawon-3 & \\
Tomato & Bari Tomato-4, 5, 10, Bari Hybrid & \\
tomato-3, 4, 8 & \\
Soybean & Shova & \\
Coconut & Bari Soyabin-6 & \\
& Bari coconut-1, Bari coconut- 2 &
\end{tabular}




\section{TABLE 8.4}

\section{Locally Led Adaptations Being Practiced in Coastal Areas}

$\begin{array}{cll}\text { No } & \text { Community-Based Adaptation Techniques } & \text { Location(s) } \\ 1 & \begin{array}{l}\text { Integrated farming approach } \\ \text { (rice, fish, poultry, vegetable cultivation) }\end{array} & \text { Mongla, Bagerhat, Chila Union } \\ 2 & \begin{array}{l}\text { Floating vegetable gardening } \\ \text { (Floating bed used for crop cultivation) }\end{array} & \text { Satkhira, Khulna, Paickgacha } \\ 3 & \text { Homestead garden and vegetable on raised plinth } & \text { Pirojpur, Goplaganj, Faridpur, Jalakathi, Barisal } \\ 4 & \text { Dyke cropping techniques } & \text { Satkhira, Khulna, Paickgacha } \\ & & \text { Borguna, Patuakhali, Satkhira, Bagerhat, } \\ 5 & \text { Pitcher irrigation } & \text { Khulna, Paickgacha, Koyra } \\ 6 & \text { Fish cage farming } & \text { Satkhira, Khulna, Dacope, Koyra } \\ 7 & \text { Crab fattening techniques } & \text { Satkhira } \\ & & \text { Mongla, Bagerhat }\end{array}$

on the development of early planting varieties to avoid high temperature months, and the development of high-yielding, submergence-tolerant, and short-duration (110-120 days) rice varieties including rice varieties that are resistant to pests and diseases, salinity, inundation, drought, and temperature stress.

\subsubsection{Community-Based Adaptation (CBA) in Coastal Bangladesh}

Salinity has been engulfing new areas in the coastal region of Bangladesh. The capacity for CBA (Ayers and Forsyth 2009; Schipper et al. 2014) has increased through learning by doing and action research. In collaboration with government organizations and NGOs, the Bangladesh Centre for Advanced Studies (BCAS) and International Institute for Environment and Development (IIED) has identified a number of CBAs in Asia, Africa, Europe, and Australia that can be used as models for actions in Bangladesh (BCAS 2012). Through community consultation workshop and group discussion, we have tabulated a number of coastal communities led agricultural adaptation techniques (Table 8.4).

\subsubsection{The Sundarbans Mangrove Forest and Agriculture}

Coastal ecosystem services are becoming increasingly vulnerable to natural disasters like cyclones. The Sundarbans mangrove forest of Bangladesh is the largest mangrove forest in the world. It works as a buffer, protecting coastlines and attenuating storm surges and wind speed (Akber et al. 2018). It, therefore, plays a vital role in reducing the vulnerability of coastal communities to tropical cyclones (Barua et al. 2010). Our investigation has established that about $21 \%$ of cyclonic storm surges hit the Sundarbans with low consequent damage to communities. From group discussion and consultation, we suggest that there is a need for better mangrove management and coastal afforestation/reforestation which can reduce cyclonic damage and improve agricultural systems in coastal areas.

\subsubsection{Coastal Embankment and Agricultural Development}

Bangladesh has $5,017 \mathrm{~km}$ of embankments to protect the polders in coastal areas from regular natural disasters and boost agricultural production (Brammer 2014; 
Islam et al. 2013; Mallick et al. 2011). However, due to the poor maintenance of embankments, in many places there have been increases in salinity intrusion into fields (Mahmuduzzaman et al. 2014; Nowreen et al. 2014). Poor maintenance of embankments has also increased the frequency of flash floods in coastal areas (Choudhury et al. 2004). In addition, shrimp farmers cut embankments to allow saline water into their shrimp fields which makes embankments vulnerable and easily further damaged due to tidal pressure. This pressure is highest particularly during high tides associated with the full moon (Auerbach et al. 2015; Hossain et al. 2008; Saari and Rahman 2003). Our study indicates that government organizations and NGOs should take care of embankments, raising these where required, restoring river banks, providing safe water supplies to communities, and installing tube wells and rainwater harvesting facilities in vulnerable villages.

\subsection{CONCLUSIONS - A WAY FORWARD}

Our study has found that coastal areas are being adversely affected by coastal flood, cyclones, storm surges, salinity ingression, and extreme events associated with climate change. The lives and livelihoods of the common people are severely affected by climate change stresses in all the study areas. The poor, women and marginal communities are particularly exposed and vulnerable to the impacts of these hazards. Agricultural land in coastal areas has been damaged due to the soil salinization, flooding, the rising seawater level, and scarcity of freshwater. Despite efforts to adapt, communities are on a sliding downward spiral due to increasing salinity.

Our study has shown that during the dry (rabi) season irrigation with more saline canal water has significant adverse effects on the yield of maize, watermelon, and pumpkin (Murad et al. 2018). Our study has suggested that a disaster early warning system, better coastal afforestation and reforestation, embankment improvement, the growth of flood and salt-tolerant crops, and resilient crop management practices could help reduce the loss of agricultural production. Authorities should ensure the availability of quality agriculture inputs and equipment including seeds, fertilizers and pesticides, power tillers, pumps, and spray machines. A key intervention is the implementation of community led adaptation techniques.

It is evident from the analysis of this chapter that there is an urgent need for organized, structured, and rigorous scientific research in Bangladesh that is conducted in partnership with affected communities. However, these issues are not confined to Bangladesh: they are worldwide. Overall, the global research base for saline agriculture is still weak and at an early stage. The challenges to agriculture from salinity are increasing with the increase in SLR, and with climate change, cyclones are increasing in frequency, and intensity across the world. Saline agriculture affects several different types of regions and ecosystems. These include the coastal areas, deltas interacting with marine water, small islands of many countries, and the Small Island Developing States (SIDS). All of these are particularly vulnerable to the ingress of increasing salinity. Salinity affects surface land, water, and groundwater systems. No country can undertake all the different components, enhanced resilience, growth and productivity in crops, vegetables, fisheries, livestock, and poultry, which are most needed for the survival and sustainability of coastal communities. 
There is a strong need to develop global saline agriculture research systems with regional hubs and country-based programs to advance and exchange research, undertake field trials, and advance existing, new, and more appropriate crops to ensure the survival, sustainability, and consumption of agriculture products from the coastal saline agriculture systems.

For these, significant organizational planning, technical capacities, infrastructure, and financing would be required. These aspects are being dealt with in the first paper of this book (Vellinga et al. 2019). It is most urgent that we rapidly improve saline agriculture systems. Otherwise, huge populations and many communities will be forced to migrate or be forcibly displaced. In many countries, such as Bangladesh, such migration would create huge additional problems for both guest and host communities. National agricultural research systems-NARS, appropriate national coastal agencies, international organizations such as FAO, WFP, IFAD, IRRI, World Bank group, and other international financial institution, such as Asian, African, Latin American Development Banks will need to be involved in a national, regional, and global initiatives on saline agriculture research, development, implementation, marketing, and financing. The building of capacity and resilience in affected communities will be the key objectives of these initiatives.

\section{ACKNOWLEDGMENTS}

This manuscript was prepared based on the output of multiyear and multiple projects of the BCAS. The authors are grateful to the Department of Environment (DoE) for providing the necessary support and related project reports, the Bangladesh Water Development Board (BWDB) for providing the salinity data, the Water Resources Planning Organization (WARPO) for coastal land data, the Department of Agricultural Extension (DAE) for information about coastal agriculture, the Bangladesh Agricultural Research Institute (BARI) for information on crop salttolerant varieties, the Bangladesh Agricultural Research Council (BARC) for crop and soil data, and the Soil Resource Development Institute (SRDI) for soil salinity data. We are grateful to local-level NGOs particularly to communities and their participants in assisting our research.

\section{REFERENCES}

Akber, M. A., M. M. Patwary, M. A. Islam, M. R. Rahman. 2018. Storm protection service of the Sundarbans mangrove forest, Bangladesh. Natural Hazards 94, 405-418.

Alam, M. Z., L. Carpenter-Boggs, S. Mitra, et al. 2017. Effect of salinity intrusion on food crops, livestock, and fish species at Kalapara Coastal Belt in Bangladesh. Journal of Food Quality 2017, ID 2045157, 23-46

Amores, M. J., F. Verones, C. Raptis, R. Juraske, S. Pfister, F. Stoessel. 2013. Biodiversity impacts from salinity increase in a coastal wetland. Environmental Science and Technology 47, 6384-6392.

Aryal, J. P, T. B. Sapkota, D. B. Rahut, T. J. Krupnik, S. Shahrin, M. Jat. 2020. Major climate risks and adaptation strategies of smallholder farmers in coastal Bangladesh. Environmental Management 66, 105. 
Auerbach, L., J. S. Goodbred, D. Mondal C. et al. 2015. Flood risk of natural and embanked landscapes on the Ganges-Brahmaputra tidal delta plain. Nature Climate Change 5(2), $153-157$.

Ayers, J., and T. Forsyth. 2009. Community-based adaptation to climate change. Environment: Science and Policy for Sustainable Development 51, 22-31.

Barbier, E. B. 2015. Climate change impacts on rural poverty in low-elevation coastal zones, United States: The World Bank.

Barua, P., S. Chowdhury, S. Sarker. 2010. Climate change and its risk reduction by mangrove ecosystem of Bangladesh. Bangladesh Research Publication Journal 4, 208-225.

Baten, M. A., L. Seal, K. S. Lisa. 2015. Salinity intrusion in interior coast of Bangladesh: Challenges to agriculture in south-central coastal zone. American Journal of Climate Change 4, 248.

BCAS.2012. Bangladesh Centre for Advanced Studies, Community Based Adaptation (CBA): Early learning from CBA conferences, approaches, practices, challenges and way forward (CBA1 to CAB 6), 29-50, Dhaka, Bangladesh.

BBS. 2011. Bangladesh Bureau of Statistics (BBS), population \& housing census 2011, Statistics Division, Ministry of Planning, Government of the People's Republic of Bangladesh.

BBS. 2015. Bangladesh Bureau of Statistics (BBS), Bangladesh disaster related statistics 2015: climate change and natural disaster perspectives, Statistics and Informatics Division, Ministry of Planning, Government of the People's Republic of Bangladesh.

Brammer, H. 2014. Bangladesh's dynamic coastal regions and sea-level rise. Climate Risk Management 1, 51-62.

CCC. 2016. Assessment of Sea Level Rise on Bangladesh Coast through Trend Analysis, Climate Change Cell (CCC), Department of Environment, Ministry of Environment and Forests, Bangladesh.

Chen, J., and V. Mueller. 2018. Coastal climate change, soil salinity and human migration in Bangladesh. Nature Climate Change 8, 981-985.

Choudhury, N.Y, A. Paul, B. K. Paul. 2004. Impact of costal embankment on the flash flood in Bangladesh: a case study. Applied Geography 24, 241-258.

Clarke, D., S. Williams, M. Jahiruddin, K. Parks, M. Salehin. 2015. Projections of on-farm salinity in coastal Bangladesh. Environmental Science: Processes \& Impacts 17, 1127-1136.

Dasgupta, S., M. M. Hossain, M. Huq, D. Wheeler. 2014. Climate change, soil salinity, and the economics of high-yield rice production in coastal Bangladesh, United States: The World Bank.

Dasgupta, S., M. M. Hossain, M. Huq, D. Wheeler. 2015. Climate change and soil salinity: The case of coastal Bangladesh. Ambio 44, 815-826.

Dasgupta, S., M. M. Hossain, M. Huq, D. Wheeler. 2018. Climate change, salinization and high-yield rice production in coastal Bangladesh. Agricultural and Resource Economics Review 47, 66-89.

Habiba, U., M. A. Abedin, R. Shaw, A. W. R. Hassan. 2014. Salinity-induced livelihood stress in coastal region of Bangladesh. Water insecurity: A social dilemma, United Kingdom: Emerald Group Publishing Limited.

Haque, S. A. 2006. Salinity problems and crop production in coastal regions of Bangladesh. Pakistan Journal of Botany 38, 1359-1365.

Hossain, M., M. Islam, T. Sakai, M. Ishida. 2008. Impact of tropical cyclones on rural infrastructures in Bangladesh. Agricultural Engineering International: CIGR Journal 2, $1-13$.

IPCC. 2014. Intergovernmental Panel on Climate Change (IPCC) Working Group II. Climate Change 2014: Impacts, Adaptation, and Vulnerability. Philadelphia: Saunders. www. ipcc.ch/report/ar5/wg $2 /$. 
Islam, M, Arifuzzaman, H. M. Shahin, S. Nasrin. 2013. Effectiveness of vetiver root in embankment slope protection: Bangladesh perspective. International Journal of Geotechnical Engineering 7, 136-148.

Islam, M. A., N. Warwick, R. Koech, M. N. Amin, L. L. D. Bruyn. 2020. The importance of farmers' perceptions of salinity and adaptation strategies for ensuring food security: Evidence from the coastal rice growing areas of Bangladesh. Science of the Total Environment 727, 138674.

Ji, C., Y. Zhang, Q. Cheng, Y. Li, T. Jiang, X. San Liang. 2019. Analyzing the variation of the precipitation of coastal areas of eastern China and its association with sea surface temperature (SST) of other seas. Atmospheric Research 219, 114-122.

Mahmuduzzaman, M., Z. U. Ahmed, A. Nuruzzaman, F. R. S. Ahmed. 2014. Causes of salinity intrusion in coastal belt of Bangladesh. International Journal of Plant Research 4, $8-13$.

Mallick, B., K. R. Rahaman, J. Vogt. 2011. Coastal livelihood and physical infrastructure in Bangladesh after cyclone Aila. Mitigation and Adaptation Strategies for Global Change 16(6), 629-648.

Murad, K. F. I., A. Hossain, O. A. Fakir, S. K. Biswas, K. K. Sarker, R. P. Rannu, J. Timsina. 2018. Conjunctive use of saline and fresh water increases the productivity of maize in saline coastal region of Bangladesh. Agricultural Water Management 204, 262-270.

NCAR. 2020. National Center for Atmospheric Research Staff (Eds). Last modified 27 Feb 2020. "The Climate Data Guide: SST data: HadiSST v1.1.” Retrieved from https:// climatedataguide.ucar.edu/climate-data/sst-data-hadisst-v11.

Nowreen, S., M. R. Jalal, A. K. M. Shah. 2014. Historical analysis of rationalizing South West coastal polders of Bangladesh. Water Policy 16, 264-279.

Paul, B. K., and H. Rashid. 2017. Climatic hazards in coastal Bangladesh. Non-structural and structural solutions, United Kingdom: Elsevier.

Paul, P. L. C., R. W. Bell, E. G. Barrett-Lennard, E. Kabir. 2020. Variation in the yield of sunflower (Helianthus annuus L.) due to differing tillage systems is associated with variation in solute potential of the soil solution in a salt-affected coastal region of the Ganges Delta. Soil and Tillage Research 197, [104489]. https://doi.org/10.1016/j. still.2019.104489.

Rahman, M., M. S. Uddin, M. Uddin, S. A. Bagum, N. Halder, M. Hossain. 2004. Effect of different mulches on potato at the saline soil of southeastern Bangladesh. Journal of Biological Sciences 4, 1-4.

Rahman, M. M. and M. M. Rahaman. 2018. Impacts of Farakka barrage on hydrological flow of Ganges River and environment in Bangladesh. Sustainable Water Resources Management 4, 767-780.

Rasid, H., and B. Paul. 2013. Climate change in Bangladesh: confronting impending disasters, United States: Lexington Books.

Rignot, E., I. Allison, N. L. Bindoff, et al. 2009. The Copenhagen diagnosis. Updating the world on the latest climate science, The University of New South Wales Climate Change Research Centre, Sydney.

Salehin, M., M. M. A. Chowdhury, D. Clarke, S. Mondal, S. Nowreen, M. Jahiruddin. 2018. Mechanisms and drivers of soil salinity in coastal Bangladesh. Ecosystem services for well-being in deltas. Cham: Palgrave Macmillan, 333-347.

Saari, M., and S. Rahman. 2003. Development of the coastal embankment system in Bangladesh. Soft shore protection, Springer, 115-125.

Schipper, E. L. F., J. Ayers, H. Reid, S. Huq, A. Rahman. 2014. Community-based adaptation to climate change: Scaling it up, Routledge.

SRDI. 2020. Soil Resource Development Institute, subdistricts supplements 2020, Soil Resource Development Institute, Ministry of Agriculture, 'Mrittika Bhaban', Government of the People's Republic of Bangladesh. 
Thornton, P. K., R. B. Boone, J. Ramírez Villegas. 2015. Climate change impacts on livestock. Working Paper No. 120. CGIAR Research Program on Climate Change, Agriculture and Food Security (CCAFS). Copenhagen, Denmark

Uddin, M. N., A. S. Islam, S. K. Bala, G. T. Islam, S. Adhikary, D. Saha. 2019. Mapping of climate vulnerability of the coastal region of Bangladesh using principal component analysis. Applied Geography 102, 47-57.

Unnikrishnan, A., and D. Shankar. 2007. Are sea-level-rise trends along the coasts of the north Indian Ocean consistent with global estimates? Global and Planetary Change 57, 301-307.

Vellinga, P., A. Rahman, B. Wolthuis, K. Negacz, R. Choukrallah, E. G. Barrett-Lennard, T. Elzinga. 2019. Saline agriculture, building communities pushing innovation, local and global. Future saline conference, 10-13 September 2019, Leeuwarden, the Netherlands. 


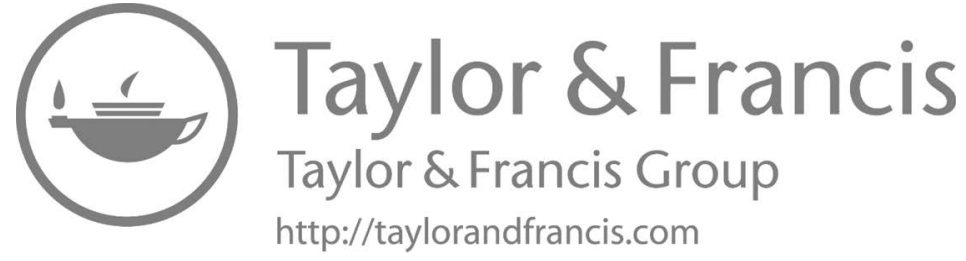

